\title{
A proposed methodological framework for the evaluation of corporate social responsibility
}

\author{
K. G. Aravossis ${ }^{1}$, N. A. Panayiotou ${ }^{1} \&$ K. Tsousi ${ }^{2}$ \\ ${ }^{I}$ Faculty of Mechanical Engineering, \\ Section of Industrial Management and Operational Research, \\ National Technical University of Athens, Greece \\ ${ }^{2}$ EFG EUROBANK ERGASIAS S.A., Greece
}

\begin{abstract}
This paper suggests a proposed methodological framework that can be followed by companies in order to implement an effective CSR programme in all areas of their operation, consisting of three distinct stages: Analysis, Execution and Performance Evaluation. The suggested framework permits the development of corporate CSR programmes adapted to the unique characteristics of each sector and company, emphasizing different stages according to organisational activities, missions and the resources that can be utilised. The framework includes weighted performance indicators relating to a company's impact on different areas of activity such as the environment, the community, human capital, shareholders and the marketplace (customers and suppliers).

Keywords: Corporate Social Responsibility (CSR), methodology, qualitative and quantitative evaluation.
\end{abstract}

\section{Introduction}

The concept of Corporate Social Responsibility (CSR) has emerged as a very 'hot' issue in the last ten years. The last few decades have seen an increase in awareness on the part of corporate entities in Western democracies that they are morally obliged to offer back to society. Social responsibility refers to the obligation of a firm, beyond that required by law or economics, to pursue longterm goals that are good for society (see for example Buchholz [1], Robbins and Decenzo [2]). The different definitions provided in the literature may refer to ethical behaviour, sustainable development, the environment, and to 
philanthropic ideas. It is important that organizations are committed to fulfilling expectations and moral obligations at the level of society. This means that right conduct takes into account the welfare of the larger society (PapasolomouDoukakis et al. [3]).

According to the World Business Council for Sustainable Development (WBCSD) [4], CSR is the ethical behaviour of a company towards society management acting responsibly in its relationships with other stakeholders who have a legitimate interest in the business, and it is the continuing commitment by business to behave ethically and contribute to economic development while improving the quality of life of the workforce and their families as well as of the local community and society at large.

Carroll [5] argues that corporations should not only be judged on their economic success but also on non-economic criteria. To fulfil the good corporate citizen role a corporation should fulfil the following responsibilities (Carroll [6]):

- Economic: earn a fair return on capital to satisfy the shareholders, deliver value for money products to satisfy customers, create new jobs and new wealth for the business, and promote innovation.

- Legal: comply with the law.

- Ethical: be moral, fair, just, respect people's rights, avoid harm or social injury and prevent harm caused by others.

- Philanthropic: perform beneficial activities for society. Lantos [7, 8]) labels this type of philanthropic CSR as "humanitarian" or "altruistic", and suggests that the organization uses it as a marketing tool to enhance the firm's image.

The above suggest that economic performance and legal conformity must not be the only drivers of corporate operation. Voluntary contribution to society is in the heart of CSR and should be a strategic decision of each organization. Lantos [7] introduced the strategic nature of CSR, providing the following classification:

- $\quad$ Ethical CSR (including economic, legal and ethical as one group)

- Altruistic CSR (philanthropic, going beyond ethical, regardless of whether or not this will benefit the business itself)

- Strategic CSR (fulfilling those philanthropic responsibilities which will benefit the firm through positive publicity and goodwill).

The area defined by advocates of CSR increasingly covers a wide range of issues such as plant closures, employee relations, human rights, corporate ethics, community relations and the environment. Indeed, CSR Europe, a membership organisation of large companies across Europe, in its reporting guidelines looks at the following areas:

- Workplace (employees)

- Marketplace (customers, suppliers)

- Environment

- Community

- Ethics

- Human rights. 
Whether or not business should undertake CSR, and the forms that responsibility should take, depends upon the economic perspective of the firm that is adopted.

The formal way of expressing the Corporate Social Responsibility orientation of an organisation is the annual CSR Report. The corporate Social Responsibility reports which have now become an annual report in addition to the traditional annual financial reports is one of the vehicles used to demonstrate how caring they have been over the financial period that has just ended and how they intend to continue to be even more so in future periods (Idowu and Towler [9]). Advocates of CSR reports have put forward some perceived benefits, which an organisation may derive from its provision. Examples are: increased customer loyalty, more supportive communities, the recruitment and retention of more talented employees, improved quality and productivity and the avoidance of potential risks related to reputation, which may arise from environmental incidents.

Cooper [10] states that the benefits may be more subtle and realised over a longer timescale than is sometimes suggested, but there is no doubt that the resulting benefit will be enormous in the long run.

The difficult task of measuring the results of CSR has been a matter of discussion both by academics and practitioners. Some of the literature on corporate social responsibility combines CSR with stakeholder theory introducing corporate social performance. The literature has attempted to describe an emerging model of the issues that lead to a coherent model of what would represent corporate social performance (Moir [11]). However, it is also designed to assist managers in thinking through social issues (Carroll [5]). Following on from Carroll and Wartick and Cochran [12], Wood [13] develops a complete model of corporate social performance. This builds upon the issues of corporate social responsibility and corporate behaviour within its context and in particular to look for alternative motivations."

Adopting Wood's framework, business might undertake corporate social behaviour, because:

- the activity relates to the business primary or secondary activity and that there is a business return (Preston and Post [14]);

- it forms part of corporate philanthropy;

- business wishes to influence particular stakeholder groups.

Wood and Jones [15] extend the CSP model by finding that the type of measure involved depends upon the particular stakeholder to be addressed. Measures they examine include measures related to reputation, or others such as corporate crime, which have been "developed for certain purposes". They observe that "although the measures that have been used so far have focused on particular areas of CSP ... they have limited use in Business Impact [16].

CSR Europe [17] states that "in order to measure their overall performance as well as their performance on specific CSR issues, companies use input, output, outcome and process indicators" (emphasis in the original). Particular indicators are proposed for companies at different stages of development from those "beginning to measure progress" through to "further improvement of their 
performance". It is interesting to note the range of areas covered in an assessment of CSR. The debate on what to measure in assessing corporate social performance and how objective measures can be obtained and verified is an issue of much current debate (e.g. Gray et al. [18]; Gonella et al. [19]), but it is clear that business is seeking a practical solution.

In their effort to measure the effects of Corporate Social Responsibility, both practitioners and academics struggle to assess the appropriate performance measurement system. For example, Wood and Jones [15] propose specific CSR measures for the different stakeholders of the organisation. CSR Europe [17] recommend the use of input, output, outcome and process indicators to the companies in order to measure the effectiveness of their CSR effort.

\section{A proposed methodological framework}

This paper suggests a proposed methodological framework that can be followed by organizations in order to implement an effective CSR program in all the areas of their operation. The methodology consists of three distinct stages (Figure 1): Analysis, Execution and Performance Evaluation. The suggested framework permits the development of corporate CSR programs adapted to the unique characteristics of each sector and company, emphasizing on different stages according to organizational activities, missions and the resources that can be utilized. The framework includes weighted performance indicators relating to a company's impact on different areas of activity such as the environment, the community, the human capital, the shareholders and the marketplace (customers and suppliers).

Feedback

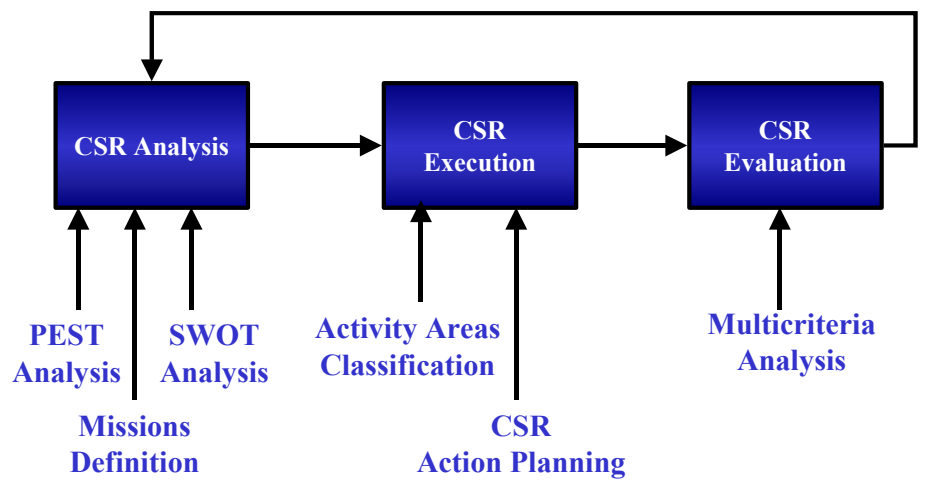

Figure 1: Overview of the suggested CSR evaluation framework.

The analysis and definition of the factors that affect the strategic orientation of the organization concerning CSR is of great importance. The analysis must assess the external and internal environment of the organisation with the use of the appropriate management methodologies. PEST (Political, Economical, Social and Technological) analysis examines factors that can affect the organisation 
directly or indirectly. The environmental assessment enables a consequent SWOT analysis (Strengths, Weaknesses, Opportunities and Threats), which combines the external assessment with an internal one. The organisation analyses the internal strengths and weaknesses it possesses and, taking into account the external environment, it defines the opportunities and threats that can recognise. The aim of the organisation must be to transform strengths into opportunities and neutralise weaknesses in order to avoid future threats. Taking into account both the internal and external strategic analysis, the organisation must define specific CSR targets. The targets must be formulated in such a way that they can be measured, but they can be either quantitative (e.g. a specific level of energy consumption) or qualitative (e.g. a specific level of customer satisfaction). The targets must be coherent with the existing organisational culture and the predefined corporate vision and must be the result of contribution of different organisational departments. The cooperation of the Top Management with the employees encourages CSR initiatives and creativity.

After the assessment of corporate practices, new specific action plans have to be defined. The selection of alternative courses of actions depends on the strategic priorities and the particular characteristics of the market in which the organisation operates. It is a usual case that an organisation must adopt different CSR approaches in different target-communities.

The second stage includes the social actions that have been decided to be undertaken by the corporation. This stage executes specific CSR plans in order to fulfil the targets set in the first stage of the proposed methodology. Based on an extensive literature review as well as on the corporate practices identified worldwide, the following basic categories of CSR initiatives have been recognised:

- Environment

- Society

- Human Capital

- Shareholders

- Customers and Suppliers

For each one of the above categories, specific CSR plans and practices are formulated and executed. From the organisational point of view, a CSR Committee should be appointed that are responsible for the coordination of CSR actions of the different organisational units in the corporation. Detailed instructions can be provided to the involved employees through specific action plans.

The third stage concerns the evaluation of Corporate Social Responsibility based on the predefined categories. This evaluation aims at the measurement of the objectives' achievement, and the investigation of suitability of the policies deployed. The evaluation process is very difficult by nature because it is mostly based on qualitative attributes, which cannot easily be translated in measurable results. As a consequence, it is preferable to identify performance measures that can be found in financial statements, which are related with the qualitative ones. The use of easily attainable performance measures enables the evaluation process, which, in other case, could prove problematic and inappropriate for 
comparisons. The examination of corporate financial results and the identification of the position of a company try to minimise the subjective judgement, even in the case that no cost elements can be found.

The proposed methodology suggests the evaluation of companies with the use of multicriteria analysis. The selected multicriteria analysis approach that was included in the methodology is the simple case of the linear additive evaluation model, expressed from Keeney and Raiffa [20]. This approach can successfully be used if the evaluation criteria can be defined independently as far the selection is concerned. A simple test performed in order to guarantee that the selected criteria are mutually independent is the ability to provide scores without the need to know the scores of other criteria. The linear model expresses the way by which an alternative (company, in our case) receives its score by combining the scores provided in the different criteria. The final score is expressed as the product of the selection score in each criterion multiplied by the weight of this criterion. The final score selection results as the weighted sum of the sub-scores of all criteria. Assuming that we have $n$ alternative selections (companies) $\left\{a_{1}\right.$, $\left.\mathrm{a}_{2}, \ldots, \mathrm{a}_{\mathrm{n}}\right\}$ and $\mathrm{m}$ selected criteria $\left\{\mathrm{c}_{1}, \mathrm{c}_{2}, \ldots \mathrm{c}_{\mathrm{m}}\right\}$ with corresponding weights $\left\{\mathrm{w}_{1}, \mathrm{w}_{2}, \ldots \mathrm{w}_{\mathrm{m}}\right\}$, then, if the score of the criteria for selection $\mathrm{a}_{\mathrm{i}}$ is $\left\{\mathrm{s}_{\mathrm{i} 1}, \mathrm{~s}_{\mathrm{i} 2}, \ldots\right.$ $\left.\mathrm{s}_{\mathrm{im}}\right\}$, the total score of criterion $\mathrm{i}$ is given by the formula:

$$
\mathrm{S}_{\mathrm{a} i}=\mathrm{w}_{1} \mathrm{~s}_{\mathrm{i} 1}+\mathrm{w}_{2} \mathrm{~s}_{\mathrm{i} 2}+\ldots+\mathrm{w}_{\mathrm{n}} \mathrm{s}_{\mathrm{ij}}=\sum_{\mathrm{j}=1}^{\mathrm{m}} \mathrm{w}_{\mathrm{j}} \mathrm{s}_{\mathrm{ij}}
$$

Scores are provided for the five categories (criteria) that were analyzed in the second stage of the proposed model $(m=5)$. Each category is decomposed into sub-categories with related quantitative and qualitative performance indicators in order to enable easier scoring. The weight of each criterion is determined by a thorough analysis of existing companies on a sector level. For example, the environmental aspect is more important to a manufacturing company compared to a service company such as a bank.

The scores of each criterion for the CSR evaluation follow a 5-degree scale, which corresponds to the following meanings:

1: Low level of CSR conformance

2: Moderate level of CSR without significant proposals

3: Moderate level of CSR with improvement potential

4: Good level of CSR conformance

5: Very good level of CSR conformance

The proposed scale does not include an 'Excellent' CSR conformance because such a classification would be against the concept of CSR which supports the voluntary participation of organisations and their effort for continuous improvement in CSR issues.

\section{Implications and further research}

The paper presents a first attempt applied in the Greek market in order to evaluate CSR initiatives. A simple multicriteria analysis was introduced in order to assess the performance of companies in their sector. The difficulty in 
quantification was recognised both in the scoring procedure as well as in the weighting process of the selected criteria. However, the calculation of a CSR score was found to be useful as a self-assessment process for companies as well as for the comparison of each company with others with similar activities and priorities. The identification of the most important CSR categories-criteria provided some useful indications for further research. Comparing these categories with the views of the Balanced Scorecard introduced by Kaplan and Norton [21], it can be seen that three of them are common at a large extend, whereas the other two are partially covered by different Balanced Scorecard views (Table 4). This finding supports Epstein and Wisner's claims [22] that the Balanced Scorecard approach can be useful to firms that want to proactively manage their environment and social aspects.

\begin{tabular}{|c|c|}
\hline CSR Evaluation Category & Balanced Scorecard View \\
\hline Environment & Learning and Growth, Customer \\
\hline Society & Learning and Growth, Customer \\
\hline Human Resources & Learning and Growth \\
\hline Shareholders & Financial \\
\hline Customers - Suppliers & Customer, Process \\
\hline
\end{tabular}

Figure 2: Comparison of balanced scorecard views and recognised CSR evaluation categories.

The use of a CSR-oriented Balanced Scorecard approach, possibly in an extended mode (with the utilization of more views), could improve the multicriteria analysis performed, offering at the same time a cause-and-effect relationship thinking. Moreover, it could more easily connect the CSR initiatives with corporate strategy and communicate the importance of its initiatives. Finally, it could help in the understanding of existing trade-offs between social, economic, and environmental effects of specific investments, something that was not covered in the present study.

\section{References}

[1] Buchholz, R.A., "Essentials of Public Policy for Management", 2nd ed., Prentice-Hall, Saddle River, NJ., 1990

[2] Robbins, S. and Decenzo, D., "Fundamentals of Management", 3rd ed., Prentice-Hall, Upper Saddle River, NJ., 2001.

[3] Papasolomou-Doukakis, I., Krambia-Kaprdis, M. and Katsioloudes, M., "Corporate Social Responsibility: The Way Forward? Maybe Not! A Preliminary Study in Cyprus”, European Business Review, Vol. 17, No. 3, pp. $263-279,2005$.

[4] WBCSD, "Corporate Social Responsibility", World Business Council for Sustainable Development, 1999. 
[5] Carroll, A.B., "A Three-Dimensional Conceptual Model of Corporate Performance”, Academy of Management Review, Vol. 4, pp. 497-505, 1979.

[6] Carroll, A.B., "The Four Faces of Corporate Citizenship", Richardson, J.E. Business Ethics 00/01, 2000.

[7] Lantos, G.P., "The Boundaries of Strategic Corporate Social Responsibility”, Journal of Consumer Marketing, Vol. 18 No. 7, pp. 595-632, 2001.

[8] Lantos, G.P., "The Ethicality of Altruistic Corporate Social Responsibility”, Journal of Consumer Marketing, Vol. 19 No. 3, pp. 205-32, 2002.

[9] Idowu, S. O. and Towler, B. A. "A Comparative Study of the Contents of Corporate Social Responsibility Reports of UK Companies", Management of Environmental Quality: An International Journal, Vol. 15, No. 4, pp. $420-437,2004$.

[10] Cooper, B., “Corporate social responsibility: the Holy Grail?”, Chartered Secretary, July, pp. 12 - 16, 2003.

[11] Moir, L., "What Do We Mean By Corporate Social Responsibility?", Corporate Governance, Vol. 1, No. 2, pp. 16 - 22, 2001.

[12] Wartick, S.L. and Cochran, P.L., "The Evolution of the Corporate Social Performance Model", Academy of Management Review, Vol. 10, pp. 758-769, 1985.

[13] Wood, D.J., "Corporate Social Performance Revisited”, Academy of Management Review, Vol. 16, pp. 691 - 718, 1991.

[14] Preston, L.E. and Post, J.E., "Private Management and Public Policy: The Principle of Public Responsibility", Prentice-Hall, Englewood Cliffs, NJ., 1975

[15] Wood, D.J. and Jones, R.E., "Stakeholder Mismatching: A Theoretical Problem in Empirical Research on Corporate Social Performance", The International Journal of Organizational Analysis, Vol. 3, pp. 229-267, 1995.

[16] Business Impact, "Winning With Integrity: a Guide to Social Responsibility", Business in the Community, London, 2000

[17] CSR Europe, Communicating Corporate Social Responsibility, CSR Europe, Brussels, 2000.

[18] Gray, R., Owen, D. and Adams, C., "Accounting and Accountability; Changes and Challenges in Corporate Social and Environmental Reporting", Prentice-Hall Europe, Harlow, 1996.

[19] Gonella, C., Pilling, A. and Zadek, S., "Making Values Count: Contemporary Experience in Social and Ethical Accounting, Auditing and Reporting", Certified Accountants Educational Trust, London, 1998

[20] Keeney, R. L. and Raiffa, H., "Decisions With Multiple Objectives: Preferences and Value Tradeoffs", John Wiley, New York, 1976 Reprinted, Cambridge University Press, 1993. 
[21] Kaplan, R. and Norton, D., "The Balanced Scorecard-Measures That Drive Performance", Harvard Business Review, January-February 1992, pp. 71-79, 1992.

[22] Epstein, M. and Wisner, P., "Good Neighbours: Implementing Social and Environmental Strategies With the BSC", Balanced Scorecard Report, May-June 2001, 3:3, Massachusetts, Harvard Business School Publishing, 2001. 